\title{
The Factors of The Infuence on Audit Quality at The Inspectorate General of Ministry of Environment and Foresty
}

\author{
Yasinta Pritama \\ Faculty of Economics and Business \\ Universitas Sumatera Utara \\ Medan, Indonesia \\ sofiakhansa@gmail.com
}

\author{
Tavi Supriana \\ Faculty of Economics and Business \\ Universitas Sumatera Utara \\ Medan, Indonesia \\ tavihutasuhut@yahoo.co.id
}

\author{
Zainul Bahri Torong \\ Faculty of Economics and \\ Business Universitas Sumatera \\ Utara Medan, Indonesia \\ zainulbahritorong@gmail.com
}

\begin{abstract}
The objective of the research was to analyze an Influence of expertise, independency, due professional care, time pressure, budget pressure, audit planning, and audit supervision on audit quality at the Inspectorate General of Ministry of Environment and Forestry. The population of this research is government internal auditor at the Inspectorate General of Ministry of Environment and Forestry. The research used causal analytic by using census and ordinal regression method with the samples of 102 respondents. The data collection is conducted using questionnaires. The results of the research showed that expertise, independency, audit planning, and audit supervision had positive influence to audit quality. Due professional care, time pressure, and budget pressure did not have any influence on the audit quality.
\end{abstract}

Keywords-Expertise; Independency; Due Professional Care; Time Pressure; Budget Pressure; Audit Planning; Audit Supervision; and Audit Quality.

\section{INTRODUCTION}

The audit quality result is something that auditors must accomplish in every audit process. The results of an audit quality are needed by the concerned parties as it will be reliable by the user as a basis for making decisions. As a result of an audit quality can help policy makers in government, to create policies and regulations that bring the welfare of the community.

The audit quality can be defined as a condition how good or not an audit has been conducted by the auditor. Inspectorate or internal auditor commonly is called APIP (Government Internal Auditor Agency). Audit quality generated by APIP is needed to encourage the realization of good governance and clean government in the government system. This is due to APIP supervision objectives is to support the smooth and precise implementation of government activities and development. The role of APIP as an internal auditor is necessary to conduct guidance, supervision, and inspection to minimize the potential for errors and fraud.

According to the Performance Report of the Inspectorate General of the Ministry of Environment and Forestry in 2015 and 2016 [9] [10], performance achievements of APIP capability levels are at level 1 (Initial) and 2 (Infrastructure), and $\mathrm{B}$ for the implementation of Government Institution Performance Accountability System (SAKIP). Whereas the Development Finance Audit Board (BPKP) regulation on Technical Guidelines for Improving APIP Capability [3], the highest level is level 5 (optimizing), that is internal audit unit has become a continuous learning unit both inside and outside the organization for continuous improvement. The highest value for the implementation of SAKIP is AA, according to the assessment of the Ministry of Administrative Reform and State Agency [18]. The absence of APIP performance is due to the inaccurate findings of audit results and by audit standards. An audit report which has no recommendations can improve agency performance.

Research on the factors affecting the quality of audit has been conducted by Pohan (2015) [19], Adiguna (2015) [1], Pakaya, et al. (2015) [17] and Hutabarat (2012) [11]. Their results show that audit planning, audit supervision, expertise, independence, and time budget pressure affect on audit quality. Nasriana et al. (2015) [16] proves that due professional care has a significant effect on audit quality. The purpose of this research is to: (1) Whether expertise, independence, due professional care, audit planning, audit supervision have a positive influence on audit quality; (2) Whether time pressure and budget pressure have a negative influence on audit quality.

\section{LITERATURE REVIEW AND HYPOTHESES DEVELOPMENT}

The expertise of an auditor is very influential on the quality of audit that will result. By APIP Audit Standards [4] that expertise is a professional skill that an auditor must possess to produce a good audit quality. Adiguna (2015) [1] states that expertise has a positive and significant impact on audit quality. So that auditor who has adequate expertise can improve the quality of the results of a better examination.

H1: Expertise positively influences on audit quality at Inspectorate General of Ministry of Environment and Forestry.

The independence of an auditor in conducting an audit is very influential on audit quality. If the auditor's independence is interrupted when conducting audit as it will prevent the auditor from providing actual information about what has been audited. The APIP Audit Standards explain that APIP Independence is required in order for the credibility of APIP's work to increase. The State Auditing Standard concludes that an auditor's independence is indispensable so as not to undermine the quality of the audit. Independence is required for the auditor to express opinions, conclusions, judgments or recommendations of the results of the investigations carried out impartially to any party. 
$\mathrm{H} 2$ : Independence positively influence on audit quality at Inspectorate General of Ministry of Environment and Forestry.

Due professional care greatly affects the process of conducting the audit to produce a good quality audit. As stated in APIP Audit Standards that auditors should use their professional expertise carefully and prudently in every assignment. The Audit Standards are stated in the execution of the examination and the preparation of the report on the result of the examination, the examiner shall use his professional proficiency carefully and thoroughly.

H3: Due professional care positively influence on audit quality at Inspectorate General of Ministry of Environment and Forestry.

Time pressure is the target time completion for each stage of the audit program cycle. Time budget pressure can affect the performance of auditors in decision making and implementation of audit procedures. Time pressure as a constraint arising from time constraints or resource constraints allocated in carrying out assignments (DeZoort et al., 1997) [6].

H4: Time pressure has a negative influence on audit quality at Inspectorate General of the Ministry of Environment and Forestry.

Reduced Audit Quality behaviors are described by Malone and Roberts (1996) [14] as actions undertaken by the auditor during performing work in which these actions can reduce the accuracy and effectiveness of the collection of audit evidence. This behavior arises because of the dilemma between inherent cost and quality, faced by the auditor in its audit environment. On the one hand, auditors must meet professional standards that encourage them to achieve high-level audit quality, but on the other hand, auditors face cost/cost constraints that make them likely to degrade audit quality.

H5: Budget pressure has a negative influence on audit quality at Inspectorate General of the Ministry of Environment and Forestry.

Audit planning is very influential to quality audit implementation. Any non-planning audit activity will result in an audit that does not match what the audit objectives are. If each audit activity is conducted audit planning in accordance with the required resources and audit techniques required it will create high audit quality. Another reason why this audit plan should be present in every audit activity is that the auditor can obtain competent evidence and achieve what the audit objectives are. Improved inspection planning will improve the quality of inspection results.

H6: Audit planning positively influence on audit quality at Inspectorate General of Ministry of Environment and Forestry.

Supervision is an ongoing action during the audit work, from audit planning to audit reports. APIP Audit Standards [4] mention that supervision is necessary to assist in the preparation of an efficient and effective audit plan, to be able to correct in case of deviations or changing circumstances and provide better and more precise audit directives.

H7: Audit supervision positively influence on audit quality at Inspectorate General of Ministry of Environment and Forestry.

\section{RESEARCH METHOD}

The population in this research is the Government Internal Supervisory Agency at the Inspectorate General of the Ministry of Environment and Forestry. The number of samples in this study was 102 people, taken by census method. Research data was obtained through face to face meetings and interviews with respondents.

Data in this research is ordinal scale data. Data with ordinal scale generally does not follow the normal distribution. Method of data analysis use ordinal regression analysis technique. The number of ordinal regression equations depends on the number of categories of ordinal variables. If the number of categories is $n$ (number of categories) then the number of equations is $n-1^{2}$. If the sum of the three categories is the sum of the two equations. If the number of categories of four then the number of equations three [5]. This study has four categories on each variable. Then the ordinal regression mathematical equation:

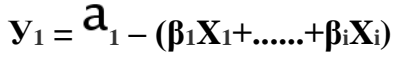

$$
\begin{aligned}
& y_{2}=a_{2}-\left(\beta_{1} X_{1}+\ldots . . .+\beta_{i} X_{i}\right) \\
& y_{3}=a_{3-}\left(\beta_{1} X_{1}+\ldots . .+\beta_{i} X_{i}\right)
\end{aligned}
$$

Keterangan:

$\mathrm{y}_{1}=$ the first logit equation

$\mathrm{y}_{2}=$ the second logit equation

$\mathrm{y}_{3}=$ the third logit equation

$\mathbf{a}_{1}=$ the first equation constant

$\mathbf{a}_{2}=$ the second equation constant

$\mathbf{a}_{3}=$ the third equation constant

$X_{1}=$ the first dependen variable

$\beta_{1}=$ the first coefficient dependen variable

According to [5], the relationship between the dependent variable and the independent variable is tested by testing the beta value (coefficient) and the confidence interval of each variable. The beta value is tested by Wald test, while the confidence interval is calculated by the confidence interval formula (signification). The Wald test is identical to the partial $\mathrm{t}$ on the Ordinary Least Square (OLS). 
IV. RESULT AND DISCUSSION

Table 1: The result of data analyze

\begin{tabular}{|c|c|c|c|c|c|c|}
\hline Variable & Category & Estimates & Std.Error & Wald & df & Sig. \\
\hline \multirow{3}{*}{$\mathrm{X} 1$ (expertise) } & {$[\mathrm{Y}=2.00]$} & -1.126 & .708 & 2.531 & 1 & .112 \\
\hline & {$[\mathrm{Y}=3,00]$} & 1.597 & .650 & 6.039 & 1 & .014 \\
\hline & $\mathrm{X} 1$ & .068 & .031 & 4.783 & 1 & $.029 *$ \\
\hline \multirow{3}{*}{ X2 (independence) } & {$[\mathrm{Y}=2.00]$} & .940 & .814 & 1.334 & 1 & .248 \\
\hline & {$[\mathrm{Y}=3,00]$} & 3.001 & .877 & 11.705 & 1 & .001 \\
\hline & $\mathrm{X} 2$ & .051 & .022 & 5.531 & 1 & $.019 *$ \\
\hline \multirow{3}{*}{ X3 (due professional care) } & {$[\mathrm{Y}=2.00]$} & -.096 & 1.580 & .004 & 1 & .952 \\
\hline & {$[\mathrm{Y}=3.00]$} & 3.257 & 1.620 & 4.042 & 1 & .044 \\
\hline & X3 & .085 & .055 & 2.321 & 1 & .128 \\
\hline \multirow{3}{*}{ X4 (time pressure) } & {$[\mathrm{Y}=2.00]$} & -4.871 & 2.215 & 4.835 & 1 & .028 \\
\hline & {$[Y=3.00]$} & -.162 & 1.683 & .009 & 1 & .923 \\
\hline & $\mathrm{X} 4$ & -.265 & .519 & .261 & 1 & .609 \\
\hline \multirow{3}{*}{ X5 (budget pressure) } & {$[\mathrm{Y}=2.00]$} & -1.536 & .548 & 7.865 & 1 & .005 \\
\hline & {$[\mathrm{Y}=3.00]$} & .431 & .537 & .644 & 1 & .422 \\
\hline & $\mathrm{X} 5$ & -.178 & .157 & 1.286 & 1 & .257 \\
\hline \multirow{3}{*}{ X6 (audit planning) } & {$[\mathrm{Y}=2.00]$} & .940 & 1.531 & .377 & 1 & .539 \\
\hline & {$[Y=3.00]$} & 4.371 & 1.605 & 7.416 & 1 & .006 \\
\hline & X6 & .101 & .045 & 5.062 & 1 & $.024 *$ \\
\hline \multirow{3}{*}{ X7 (audit supervision) } & {$[\mathrm{Y}=2.00]$} & .494 & 1.203 & .168 & 1 & .682 \\
\hline & {$[\mathrm{Y}=3.00]$} & 3.975 & 1.282 & 9.615 & 1 & .002 \\
\hline & $\mathrm{X} 7$ & .092 & .036 & 6.379 & 1 & $012 *$ \\
\hline
\end{tabular}

Table 1 shows that expertise has a positive influence on audit quality. The results of this study are in line with previous opinions and research such as Adiguna (2015) [1], Efendy (2010) [7], Lastanti (2005) [13], APIP audit standards [4] that audit should be carried out by people with sufficient technical skills and training as auditors. In government audits, auditors are required to posses and improve skills or expertise not only in audit methods and techniques but any matters involving government such as government organizations, functions, programs and activities. The level of auditor expertise in this research is sufficient to produce a good audit quality. However, it still needs continuous education or training to increase knowledge, where technical regulations will continue to growing in line with the Ministry of Environment and Forestry policy.

Table 1 shows that independence has a positive influence on audit quality. The results of this study are in line with APIP Audit Standards, State Auditing Standards (SPKN), and previous research from Adiguna (2015) [1], Kadhafi, et al. (2014) [12], Najib (2013) [15] and Apriliyani, et.al (2013) [2] auditing requires an attitude of independence to reduce interference from internal and external auditors. Auditor independence is one of the important factors to produce a quality audit. Independence is required in order for the auditor to express opinions, conclusions, judgments or recommendations of the results of the investigations carried out impartially to any party.

The results of this research indicate due professional care has no influence on audit quality. This indicates that the auditor's attitude has not been positive yet and has not had a significant impact on the quality of the resulting audit, so it needs to be improved to increase the reasonable confidence in producing audit quality that can improve the performance of the Ministry of Environment and Forestry.

APIP Audit Standards [4] and Pohan (2015) [19] that in making audit planning an auditor should set objectives, scope, and methodology and resource allocation. Determination of this goal is to detect any weaknesses of the internal control system, non-compliance with laws and regulations, and fraud. In order to obtain sufficient
The lack of accuracy and thoroughness of the auditor in this study can be caused by the limited time and budget available and the extent of the audit scope in the implementation of the audit. As conducting audit, the auditor sees the deviations that occur only from the surface rather than in depth. Facts in the field are often happens that the work unit has not functioning the system of internal control program properly. So the volume of work of auditors in the field audit process remains high. This research is in line with the results of research by Adiguna (2015) [1], Najib (2013) [15] and Apriliyani, et al. (2013) [2] that partially due professional care has no significant effect on audit quality.

Table 1 shows that time pressure does not influence audit quality. The results of this research support the results of previous studies conducted by Fitriani et al. (2011) [8]. This is because in conducting each assignment given, an auditor already has a time allocation tailored to the complexity of the task given so that the auditor should be able to carry out the task given efficiently. Time pressure encourages and challenges auditors to work more actively and selectively in assessing information so that it can produce good audit quality. The existence of a skilled level of auditor expertise and supported by good audit planning, then the time pressure that occurs does not affect the auditor's work. This research shows that budget pressure does not affect the dependent variable of audit quality. Budget pressure has no influence on audit quality. That is due to the auditor is independent, with effective and efficient time management, supported by good audit planning and supervision.

The results of this research indicate that audit planning has a positive influence on audit quality. It means that when audit planning increase the audit quality will also increase. The results of this research are in line with competent evidence, help keep audit costs incurred in a reasonable amount and avoid misunderstandings.

Table 1 has showed that audit supervision has a positive influence on audit quality. These results are in line with the APIP Audit Standards and the Pohan research (2015) [19], which the auditor's work must be adequately 
supervised to ensure achievement of the objectives, quality assurance and improved auditor capacity. With good supervision, the audit team understands the audit objectives and plans, the audit is carried out in accordance with audit standards, audit procedures have been followed, the audit work paper contains evidence supporting the findings and recommendations.

Based on the results of tests conducted using ordinal regression it can be concluded, that the expertise, independence, audit planning and audit supervision have a positive influence on audit quality. Due professional care, time pressure, and budget pressure did not have any influence to the audit quality.

\section{References}

[1] Adiguna. Mohamad, "The factors of the influence on audit quality at the Bogor District Inspectorate", Management journal, Postgraduate Institute Pertanian Bogor, Volume 13 No 1, 2015.

[2] Apriliyani. Ika Berty, Anugerah. Rita, and Nurmayanti. Poppy, "The factors of the influence on APIP audit quality at the Riau Province Inspectorate", Publish journal, Universitas Riau in Pekanbaru, Volume 5 No 3, 145-158, November 2013.

[3] Development Finance Audit Board (BPKP), Technical Guidelines for Improving APIP Capability, Jakarta, 2011.

[4] Development Finance Audit Board (BPKP), APIP Audit Standards, Jakarta, 2013.

[5] Dahlan. Sopiyudin. M, Ordinal regression with SPSS program practically (E-book Version), www.bukusopiyudin.com. Epidemiologi Indonesia, Jakarta, 2014.

[6] DeZoort. F.T, and Lord. A.T. A, "Review and synthesis of pressure effects research in accounting", Journal of Accounting Literature, 1997.

[7] Efendy. Muhammad. Taufiq, "Influnce of competency, independent, and motivation on APIP audit quality of the Government Financial Report Supervision at the Gorontalo Province", Universitas Diponegoro, 2010.
[8] Fitriany. Gani. L, Siregar. S.V, Marganingsih. A, and Anggraita. V. "The analyze factor of influence auditors job satisfaction and Performance effect with auditor rotation". Indonesia accounting and financial journal, 2011.

[9] General Inspectorate of Ministry of Environment and Forestry, The Goverment Performance Report for 2015 scope, Jakarta, 2016.

[10] General Inspectorate of Ministry of Environment and Forestry, The Government Performance Report for 2016 scope, Jakarta, 2017.

[11] Hutabarat. Goodman, "The influence of the experience, time budget pressure and auditor attitude on quality audit", Universitas Satya Negara Indonesia, Scientific journal ESAI Volume 6, Nomor $1,2012$.

[12] Kadhafi. M, Nadirsyah, and Abdullah. Syukri, "The influnce of the independency, attitude, and audit standarts on quality audit at the Aceh province inspectorate", Accounting journal at the post graduate Universitas Syiah Kuala, 93-103. 2014.

[13] Lastanti. Hexana. Sri, "The study of competency and independency public auditor on the financial fraud", Media of the accounting riset and information, Volume 5 No 1, April 2005.

[14] Malone. Charles. F, and Roberts, Factor associated with the incidence of reduced audit quality behaviour, Auditing, September. 1996.

[15] Najib. Ayu. Dewi. Riharna, "The influnce of expertise, independency, and attitude on quality audit - Study at the goverment auditor BPKP at the South Sulawesi province, Universitas Hasanuddin Journal, 2013.

[16] Nasriana. Basri. Hasan, and Abdullah. Syukriy. "The influnce of competency, independency, objectivity, due professional care, audit experiance on quality audit - Study at the Aceh district inspectorate, Accounting journal Universitas Syiah Kuala post graduate, 81-89, 2015.

[17] Pakaya. Mohamad. Reynaldhy, Pakaya. Sahmin., and Pakaya. Lukman, "The influnce of time budget pressure on quality audit at the Gorontalo province inspectorate", Universitas Negeri Gorontalo journal, 2015.

[18] The financial inspection state (Badan Pemeriksa Keuangan Republik Indonesia) regulation, State Auditing Standards, Jakarta 2007.

[19] Pohan. Nur. Aisah, "The analyze of expertise, independency, audit planning, and audit supervision on quality audit at the North Sumatera Province Inspectorate with motivation as moderating variable", Universitas Sumatera Utara journal, 2015. 